\title{
SODIUM METHITURAL: A CLINICAL STUDY ${ }^{1}$
}

\section{Gordon M. Wyant, f f a r c s, Chung Ai Chang, m D., D p h (Toronto),? and Geordis M. Aasheim, $\mathbf{M ~}^{3}$}

Sodium Methitural (Neraval $\left.{ }^{\circledR}\right)^{4}$ is one of a number of recently introduced ultra short-actıng intravenous anaesthetics Unlike other thobarbiturates, it has on one of its side chains a second sulphur atom in the form of a thiomethyl group. This is sard to accelerate the detoxification of many types of drug (1) The structural formula of methitural is

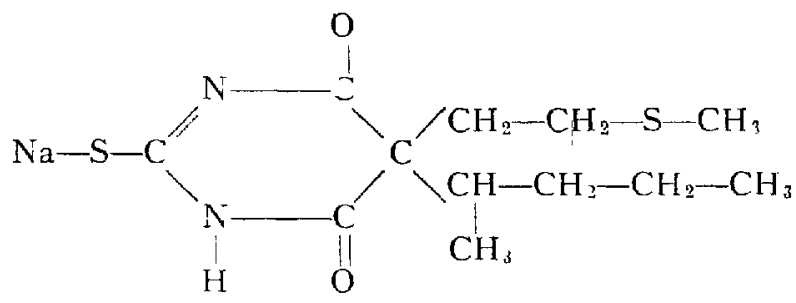

FIGTRE 1

The agent has been under investigation for over two years, and has been commercially available for one year. Its chemical and clinical properties have been described in many previous communications and reference should be made to these for detarls of chemistry and pharmacology (1-11)

Sodium methitural having been submitted to a comparative study in human volunteers $(12,13)$, it was decided to evaluate its chnical properties under operating room conditions and again compare the drug with the standard intravenous barbiturate-sodium thiopental.

\section{METHOD}

In order to exclude as many variables as possible, the study was limited to minor gynaecological procedures such as D \& C, biopsy of cervix, etc, only patıents in physical status I and II (classification of the American Society of Anesthesiologists) were mcluded and all adminstrations and evaluations were done by the authors themselves. The agents were given in freshly prepared 2.5 per cent solutions by the، intermittent injection technique Additional amounts of each drug were administered when signs of too light a level of anaesthesia

1Presented at the Meeting of the Canadian Anaesthetssts' Society, Western Division, Calgary, March 13-15, 1958

2From the Department of Anaesthesia, University of Saskatchewan College of Medicine and University Hospital, Saskatoon, Sask

3Now Department of Anesthesiology, University of Washington, Seatile, Washington, U S A

${ }^{4}$ Supphes of Neraval@ were made avalable through the courtesy of the Schering Corporation, Montreal, P Q 
appeared clinically. All patients received oxygen by mask in a semi-closed system at a flow of 6 litres/min.; no other anaesthetics were administered. Muscle relaxants were given only when relaxation for pelvic exammation proved inadequate. Injections were made into the median cubital vein and as far as possible at a standard rate of $25 \mathrm{mg} / \mathrm{sec}$. for induction

The premedicated senes received meperidme $50 \mathrm{mg}$ and atropine $04 \mathrm{mg}$. intramuscularly Atropine $04 \mathrm{mg}$. was given to the "no premedication" series The drugs were given intravenously and in reduced doses when there was not time for the intramuscular route to be effective

Both experimental and commercial methitural were tested since it had been the clinical impression of some investigators that the two had slightly different properties In the study 42 cases of anaesthesia by experimental methitural without premedication and 57 by the commercial material without premedication were avallable for analysis. In a further 50 cases, commercial methitural was used with the premedication mentioned above, in another 50 cases sodum thiopental 25 per cent was used with premedication

\section{Discussion of Results}

The following comparisons were made (A) thıopental with premedication and commercial methitural with premedication, (B) commercial methitural with premedication and commerciall methitural without premedication (this analysis should clarify the influence of premedication upon methitural anaesthesia); and (C) commercial methitural ws thout premedication and experimental methitural without premedication.

Since many early publications were based on experiences with the experımental material, these would have to be reinterpreted if the present study should reveal, significant differences between expenmental and commercial methitural.

Age (Table I)

TABLE I

\begin{tabular}{|c|c|c|c|c|c|c|c|}
\hline & & \multirow{2}{*}{$\begin{array}{l}\text { Oldest } \\
\text { (yrs) }\end{array}$} & \multirow{2}{*}{$\begin{array}{l}\text { Youngest } \\
\text { (yrs) }\end{array}$} & \multicolumn{2}{|c|}{ Mean } & \multirow[b]{2}{*}{ S D. } & \multirow[b]{2}{*}{$\mathfrak{f}$} \\
\hline & & & & (yrs) & $\overline{(m o)}$ & & \\
\hline Thropental c & $(50)$ & 159 & 12 & 36 & 3 & 1181 & \multirow{4}{*}{$\begin{array}{l}\text { A } 0677 \\
\text { В } 0258 \\
\text { С } 0.692\end{array}$} \\
\hline Methitural c & $(50)$ & 72 & 16 & 34 & 9 & 1090 & \\
\hline Methitural s & $(57)$ & 75 & 13 & 34 & 2 & 1174 & \\
\hline Methitural $(\exp ) s$ & $(42)$ & 50 & 19 & 32 & $10^{-}$ & 789 & \\
\hline
\end{tabular}

"Significant $(P<.05)$

*Highly significant $(P<01)$

$S D$ Standard Deviation

$\uparrow$ Companson

The oldest and the youngest patient in each group has been listed, as has the mean age for each group. Statistical analysis of the three standard comparisons $A, B$ and $C$ failed to reveal any significant differences. 
Hëight and Weight (Table II)

Again mean values in these groups were very similar and differences in comparisons $A, B$ and $C$ were not significant. Hence, these four groups were comparable as far as age, height and weight are concerned

TABLE II

\begin{tabular}{|c|c|c|c|c|c|c|c|}
\hline & & $\begin{array}{l}\text { Mean heigh } \\
\text { (in) }\end{array}$ & $\mathrm{SD}$ & $t$ & $\begin{array}{l}\text { Mean we } \\
\text { (Ibs) }\end{array}$ & S D & $t$ \\
\hline Thiopental $c$ & $(50)$ & 6310 & 216 & \multirow{4}{*}{$\begin{array}{l}\text { A } 0 \\
\text { B-1 } 647 \\
\text { C-0 } 339\end{array}$} & 136.52 & 2448 & \multirow{4}{*}{$\begin{array}{l}\text { A-1, } 211 \\
\text { B-0 } 199 \\
\text { C-0 } 070\end{array}$} \\
\hline Methitural c & $(50)$ & 6310 & 231 & & 12969 & 2364 & \\
\hline Methitural s & $(-57)$ & 6394 & 298 & & 12888 & 1742 & \\
\hline Methitural $(\exp ) s$ & $(42)$ & 6375 & 255 & & 12861 & 2012 & \\
\hline
\end{tabular}

Significant $(P<05)$

* Highly significant $(P<01)$

$\mathrm{SD}$ Standard Deviation
+ Comparison

Time from Premedication to Induction of Anaesthesia (Table III)

Although in each group there was a large difference in the time from premedication to induction, the means in each group were faurly close As every anaesthetist knows, it is almost impossible to standardize this particular variable even within reasonable limits because of the uncertainties of the operative schedule. The differences in comparisons A, B and C are not sıgnificant We may therefore assume that the time of premedication did not influence the various aspects of the present study.

TABLE III

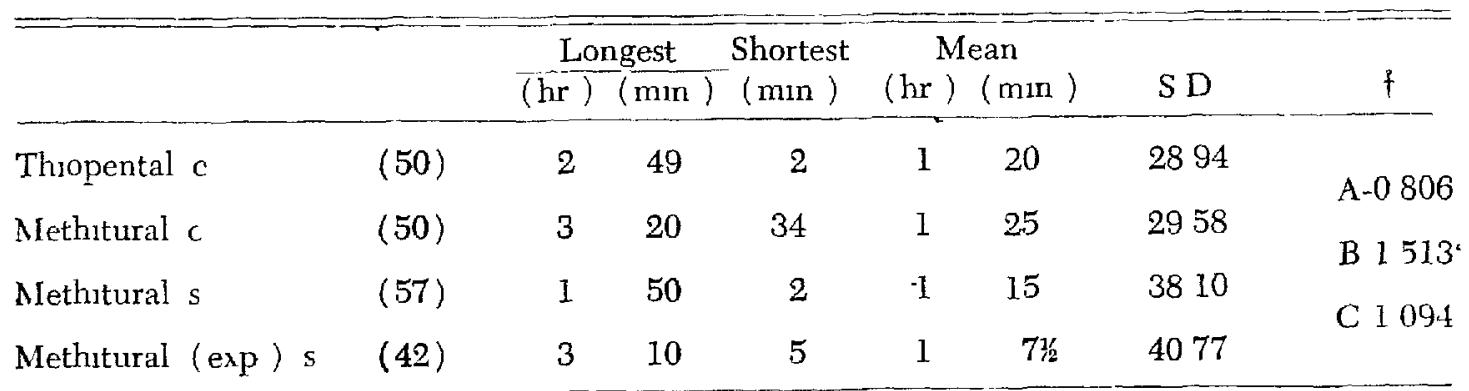

- Significant $(P<.05)$

${ }^{\circ}$ Highly significant $(P<.01)$
S D Standard Deviation

†. Comparison

\section{Duration of Anaesthesia (Table IV)}

The time from induction of anaesthesia to the end of operation was noted. The longest and the shortest anaesthetic in each group has been listed and the mean for each _calculated. The average duration in the thiopental group was significantly longer than that in the methitural group with premedication (comparison A). This may have been a purely fortuitous finding or an expression of the better operating conditions provided by thiopental. No such differences existed in comparisons $\mathrm{B}$ and $\mathrm{C}$. 
WYANT et $a l$.: SODIUM METHITURAL

TABLE IV

\begin{tabular}{|c|c|c|c|c|c|c|c|}
\hline & & \multirow[t]{2}{*}{ Longest } & \multirow{2}{*}{$\begin{array}{c}\text { Shortest } \\
\text { (min.) }\end{array}$} & \multicolumn{2}{|c|}{ Mean } & \multirow[b]{2}{*}{ S.D. } & \multirow{6}{*}{$\begin{array}{l}\text { A } 3.284^{* 0} \\
\text { B- } 0.865 \\
\text { C- } 1.316\end{array}$} \\
\hline & & & & $(\min )$. & (sec.) & & \\
\hline Thiopental $c$ & $(50)$ & $29 \mathrm{~min}$. & 5 & 18 & 19 & 5.42 & \\
\hline Methitural c & $(50)$ & 28 min. & 4 & 15 & $2 \frac{1 / 2}{12}$ & 4.49 & \\
\hline Methitural s & (57) & 39 min. & 5 & 15 & 55 & 5.97 & \\
\hline Methitural (exp.) s & $(42)$ & $1 \mathrm{hr} .5 \mathrm{~min}$. & 4 & 18 & 20 & 10.72 & \\
\hline
\end{tabular}

${ }^{\circ}$ Significant $(P<.05)$

${ }^{\circ}$ Highly significant $(P<.01)$

S.D.: Standard Deviation

$t$ : Comparison

\section{Duration of Operation (Table V)}

The duration of anaesthesia being determined by the duration of the operation, it was not surprising to find that the duration of operation in the thiopental group was again significantly longer than that in the methitural group with premedication and that differences in comparisons $\mathrm{B}$ and $\mathrm{C}$ were once more not significant.

TABLE V

\begin{tabular}{lccccccc}
\hline \hline & & $\begin{array}{c}\text { Longest } \\
\text { (min.) }\end{array}$ & $\begin{array}{c}\text { Shortest } \\
\text { (min.) }\end{array}$ & $\begin{array}{c}\text { Mean } \\
\text { (min.) }\end{array}$ & (sec.) & S.D. & $\ddagger$ \\
\hline Thiopental c & $(50)$ & 27 & 2 & 12 & 66 & 5.26 & A $3.088^{* *}$ \\
Methitural c & $(50)$ & 23 & 4 & 9 & 69 & 4.26 & B 0.990 \\
Methitural s & $(57)$ & 33 & 1 & 8 & 76 & 5.41 & C-1.224 \\
Methitural (exp.) s & $(42)$ & 37 & 1 & 10 & 52 & 8.08 & \\
\hline
\end{tabular}

"Significant $(P<.05)$

*Highly significant $(P<.01)$

S.D.: Standard Deviation

F: Comparison

\section{Total Anaesthetic Dose (Table VI)}

Here all three differences were significant. In comparison. A, this was anexpression of the greater anaesthetic potency of thiopental as compared with methitural. Thiopental was almost twice as potent milligram for milligram when

TABLE VI

\begin{tabular}{lcccccc}
\hline & & $\begin{array}{c}\text { Maxinium } \\
(\mathrm{mg} .)\end{array}$ & $\begin{array}{c}\text { Minimum } \\
(\mathrm{mg} .)\end{array}$ & $\begin{array}{c}\text { Mean } \\
(\mathrm{mg})\end{array}$ & S.D. & \\
\hline Thiopental c & $(50)$ & 1000 & 250 & 585.5 & 146.39 & A-12.183*0 \\
Methitural c & $(50)$ & 1500 & 625 & 1021 & 206.50 & B- $2.635^{\circ *}$ \\
Methitural s & $(57)$ & 1750 & 600 & 1143 & 272.25 & C- $3.158^{\circ *}$ \\
Methitural (exp.) s & $(42)$ & 2500 & 625 & 1348 & 370.24 & \\
\hline
\end{tabular}

${ }^{\circ}$ Significant $(P<.05)$

${ }^{\circ}$ "Highly significant $(P<.01)$

S.D.: Standard Deviation

t: Comparison 
comparable operating conditions were provided Comparison B confirmed a fact well known to all anaesthetısts, namely, that preoperative medication will sıgnificantly reduce the amount of a general anaesthetıc subsequently required Comparison $\mathrm{C}$ indicated that the commercial product of methitural was slightly more potent than the expenmental matenal, this may have been an expression of the greater chemical purity of the newer product

\section{Induction Dose and Maintenance Dose (Tables VII and VIII)}

Again differences in comparisons $\mathrm{A}, \mathrm{B}$ and $\mathrm{C}$ of the means were significant The reasons for this were the same as those discussed for total dose

TABLE VII

\begin{tabular}{|c|c|c|c|c|c|c|}
\hline & & $\begin{array}{c}\text { Maxumum } \\
(\mathrm{mg})\end{array}$ & $\begin{array}{c}\text { Minimum } \\
(\mathrm{mg})\end{array}$ & $\begin{array}{l}\text { Mean } \\
\text { (mg ) }\end{array}$ & SD & $\uparrow$ \\
\hline Thoopental $c$ & $(50)$ & 250 & 75 & 244 & 3012 & \multirow{4}{*}{$\begin{array}{l}\text { A-21 } 933^{\circ} \\
\text { B- } 2649^{*} \\
\text { C } 2097^{*}\end{array}$} \\
\hline Methitural c & $(50)$ & 500 & 375 & 385 & 3426 & \\
\hline Methitural s & $(57)$ & 625 & 375 & 410 & 6139 & \\
\hline Methitural $(\exp ) s$ & $(42)$ & 500 & 375 & 393 & 238.41 & \\
\hline
\end{tabular}

TABLE VIII

\begin{tabular}{|c|c|c|c|c|c|c|}
\hline & & $\begin{array}{l}\text { Maxımum } \\
\text { (mg) }\end{array}$ & $\begin{array}{c}\text { Minımum } \\
(\mathrm{mg})\end{array}$ & $\begin{array}{l}\text { Mean } \\
\text { (mg) }\end{array}$ & $S D$ & $f$ \\
\hline Thropental $c$ & $(50)$ & 750 & 0 & 3415 & 14774 & \multirow{4}{*}{$\begin{array}{l}\text { A-8 192. } \\
\text { B-2 117 } \\
\text { C-3 499. }\end{array}$} \\
\hline Methitural c & $(50)$ & 1,125 & 250 & 636 & 20684 & \\
\hline Methitural s & $(57)$ & 1,375 & 225 & 733 & 26666 & \\
\hline Methitural $(\exp ) s$ & $(42)$ & 2,000 & 250 & 964 & 36052 & \\
\hline
\end{tabular}

Dose per Minute of Anaesthesia (Table IX)

Because of the significant difference in mean duration of anaesthesia in the thiopental group as compared with the methitural group with premedication, it seemed advisable to determine the dose required per minute of anaesthesia in order to eliminate any error introduced by this discrepancy of duration. Comparison A between thiopental and methitural with premedication still showed a significant difference This was to be expected since the average total anaesthetic dose of thiopental was much less than that of methitural for operations which were on the average longer. Thiopental was therefore more than twice as potent as methitural. Although comparisons $\mathrm{B}$ and $\mathrm{C}$ were no longer'significantly 
different, it was still interesting that, on the average, less methitural was used when its admunstration followed premedication than when atropme only was given and that on the average more of the experımental material was needed than of the commercial material, confirming the preceding observatons.

TABLE IX

\begin{tabular}{lcccc}
\hline & & $\begin{array}{l}\text { Mean } \\
(\mathrm{mg})\end{array}$ & S.D & $f$ \\
\hline Thiopental c & $(50)$ & 3491 & 1514 & A-10 384.0 \\
Methitural c & $(50)$ & 7225 & 2043 & B- 1311 \\
Methitural s & $\left(5 i^{\circ}\right)$ & 7807 & 2546 & C- 1.556 \\
Methitural (exp ) s & $(49)$ & 8742 & 3228 & \\
\hline
\end{tabular}

${ }^{*}$ Signuficant $(P<05)$

* Highly significant $(P<01)$

$S$ D Standard Deviation

\section{Total Sleep Time (Table X)}

This was determined as the tume between induction and the patient's purposeful response to verbal command. Both the longest and shortest sleep tomes were listed for each group as well as the means Analysis of comparısons A, B and C falled to reveal significant differences between them. It has been claimed that sodıum methitural is a shorter acting agent than, thiopental, our findings have shown that, for comparable depth of anaesthesia in a standard operative procedure, no such difference exists between thiopental and methitural.

TABLE X

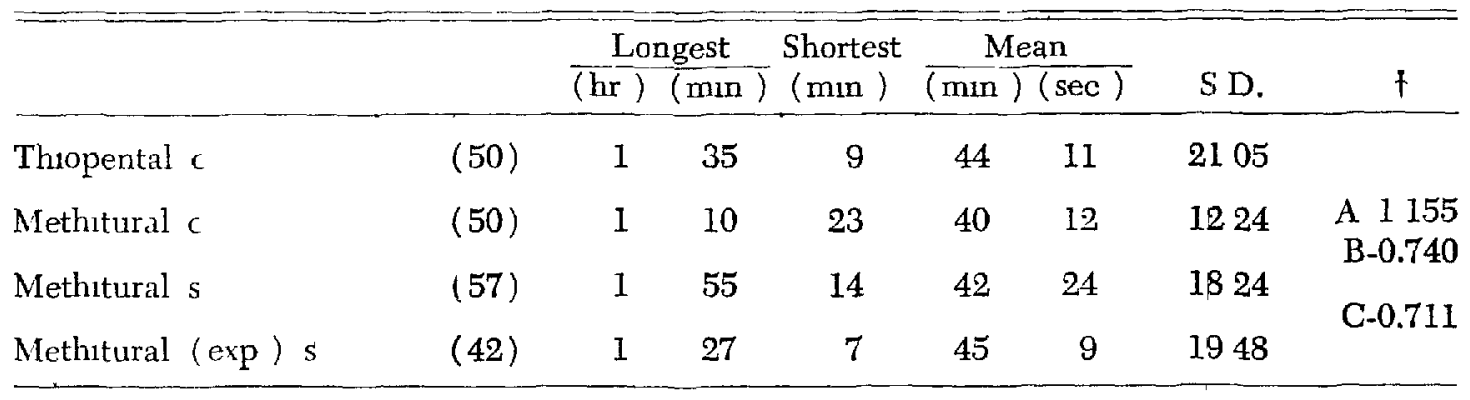

${ }^{*}$ Significant $(P<05)$

* Highly significant $(P<01)$

$S D$ Standard Deviation

Wakng Time from Last Injection (Table XI)

This was the period from the last injection untsl the time when the patient obeyed simple verbal commands. Again no statistical difference was demonstrated for the means of comparisons A, B and C The imphcations of this were the same as those discussed under total sleep time Whether a difference of wakening exists after, shorter procedures not exceeding five minutes remams a matter of speculation. 
TABLE XI

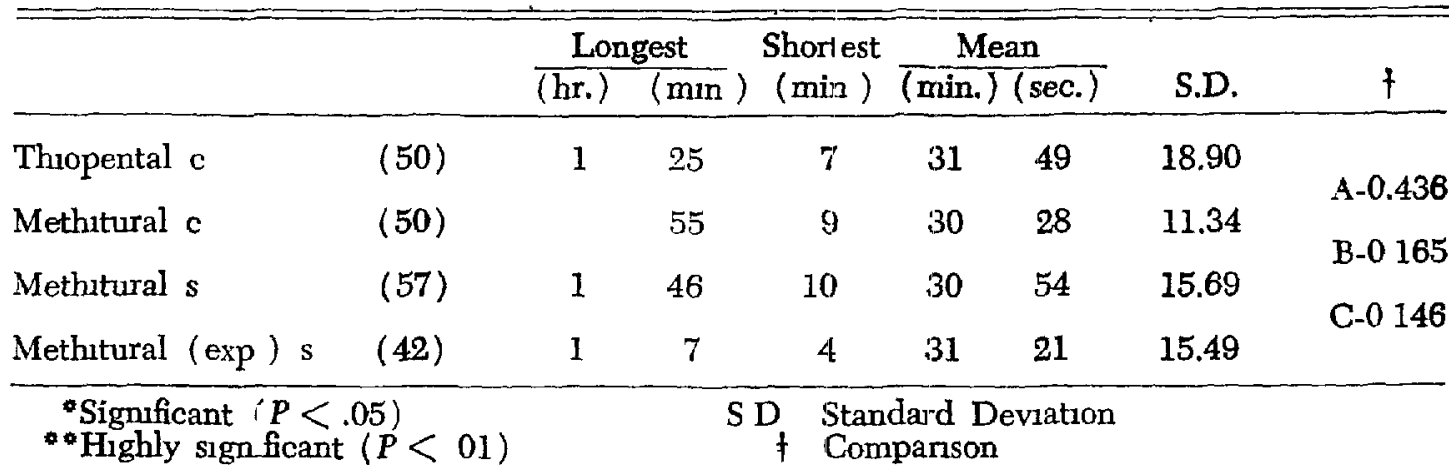

\section{Dose/Minute Sleep Time (Table XII)}

This relationship shed some additional light upon comparative potencies. Differences in comparisons A and B of the means were highly significant, which again confirmed the greater potency of thiopental and that less anaesthetic drug was needed in the presence of premedication. No significant difference could be demonstrated between experimental and commercial methitural when both were used after atropme premedication only.

TABLE XII

\begin{tabular}{|c|c|c|c|c|}
\hline & & $\begin{array}{l}\text { Mean } \\
(\mathrm{mg})\end{array}$ & $S D$ & + \\
\hline Thropental c & $(50)$ & 1557 & 972 & \multirow{4}{*}{$\begin{array}{l}\text { A- } 6709^{\circ} \\
\text { B- } 4387^{\circ} \\
\text { C-0 } 525\end{array}$} \\
\hline Methitural c & $(50)$ & 2697 & 705 & \\
\hline Methitural s & (57) & 3412 & 973 & \\
\hline Methitural $(\exp ) s$ & (42) & 3582 & 1929 & \\
\hline
\end{tabular}

\section{Side-Effects (Table XIII)}

(1) The significantly higher incidence of cough (comparison A) durng induction of methitural anaesthesia was striking. Cough was present in only 6 per cent of the patients under sodrum thiopental with premedication Although the difference in comparison $B$ was not significant, it must be noted that the incidence of cough with sodium methitural was greater without than with premedication. Although it had been a clnical impression that cough was less frequent with the commercial than with the experimental product this was not borne out by the final figures.

(2) Hiccoughs occurred with sodium thiopental in 12 per cent of cases. Although the difference as shown by companson A was not significant, the incidence with methitural was nevertheless double that with thiopental. Also hiccough with methitural often persisted throughout the operation. In the series of methitural without premedication however, the incidence was increased to 
the point where the difference in comparison B became significant. Premedication therefore reduced the incidence of hiccough under methitural. The experımental material showed a lower incidence of hiccough than commercial methitural, but the difference was not significant.

TABLE XIII

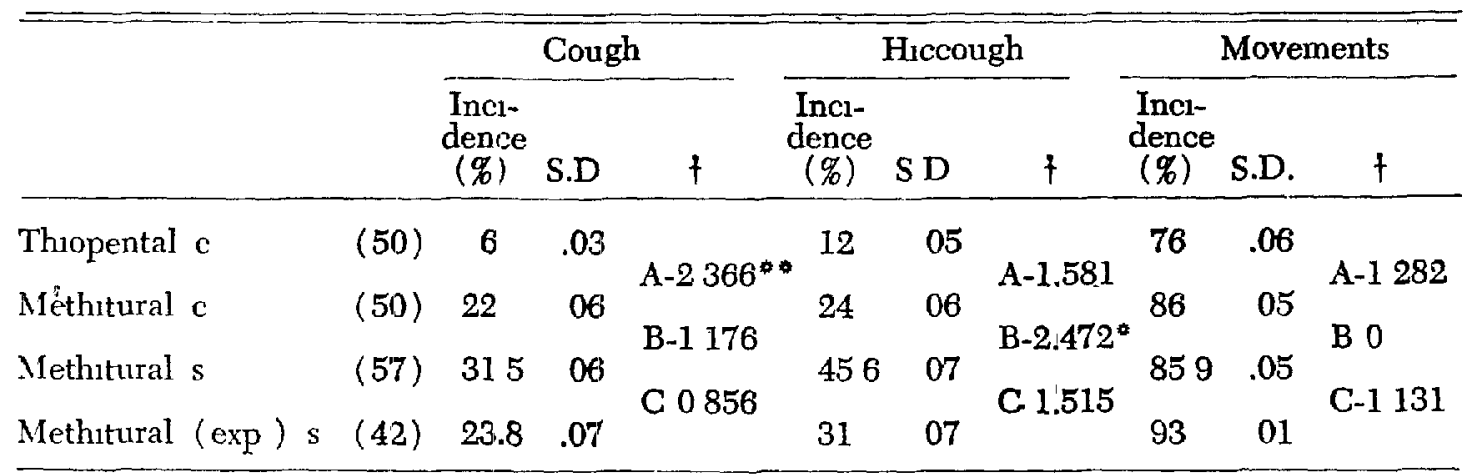

- Significant $i P<05$ )

* Highly sign ficant $(P<0.1)$

S D Standard Deviation

$f:$ Comparison

(3) Movements occurred in very many patients in all four groups and comparisons $\mathrm{A}, \mathrm{B}$ and $\mathrm{C}$ were not significant The reason for this high incidence was that slight movements were taken as an indication for additional amounts of drug. Therefore, they could not be attributed to the anaesthetic but rather to inadequate depth of anaesthesia They were always easily controlled by further injections and were often unnoticed by the surgeon Movements involving the legs to the point where they were noticed by the surgeon were classified as moderate. These movements could not always be entirely controlled by further injections. Gross movements involved the entire body and included withdrawal of the pelvis making continuation of the operation difficult and annoying to the surgeon (Table XIV)

TABLE XIV

\begin{tabular}{|c|c|c|c|c|c|}
\hline & & None & Slight & Moderate & Severe \\
\hline $\begin{array}{l}\text { Thiopental c } \\
\text { Methitural c } \\
\text { Methitural s } \\
\text { Methitural (exp.) s }\end{array}$ & $\begin{array}{l}(50) \\
(50 \\
(57 \\
42\end{array}$ & $\begin{array}{l}12(24 \%) \\
7,14 \%) \\
8,14 \%) \\
3(7 \%)\end{array}$ & $\begin{array}{l}38(76 \%) \\
34(68 \%) \\
32(56 \%) \\
24(57 \%)\end{array}$ & $\begin{array}{c:c}0 & \\
5 & 10 \%) \\
10 & 17.5 \%) \\
11 & 26.5 \%)\end{array}$ & $\begin{array}{l}0 \\
4(8 \%) \\
7(125 \%) \\
4,95 \%)\end{array}$ \\
\hline
\end{tabular}

No disturbing movements other than those indicatıng the need for more drug occurred under thiopental anaesthesia. Moderate and gross movements were seen more frequently when methitural was not preceded by premedication than when it had been given. On three occasions, anaesthesia could not be maintained with methitural and a change had to be made to nitrous oxnde and trichlorethylene. These cases were not included in the analyses. There was little if any difference between the experimental and the commercial material in these respects.

It was realized that repeated injection was not necessarily the most desirable 
technique for sodium methitural which might have applications in anaesthesia other than as the sole agent for maintenance of anaesthesia. Indeed we rarely ever use sodium thiopental in this way

\section{Apnoea (Table XV)}

The clinical impression that sodium thiopental depressed respuration more than sodium methitural has been borne out. The difference in comparison A was significant for both the higher incidence and the longer duration of apnoea following sodium thiopental induction, the incidence being as high as 94 per cent. There was no significant difference between methitural with and without premedication although numerically the incidence was higher when premedıcation was not used.

TABLE XV

\begin{tabular}{|c|c|c|c|c|c|c|c|c|c|}
\hline & & $\begin{array}{l}\text { Inc1- } \\
\text { dence }\end{array}$ & SD & $t$ & $\frac{\text { Dur }}{\begin{array}{c}\text { Long- } \\
\text { est }\end{array}}$ & $\frac{\text { Short- }}{\begin{array}{c}\text { est } \\
\text { est }\end{array}}$ & Mean & $\underline{S D}$ & $t$ \\
\hline Thiopental c & $(50)$ & $94 \%(47)$ & .03 & \multirow{4}{*}{$\begin{array}{l}\text { A } 4622^{*} \\
\text { B-1 } 304 \\
\text { C } 1.093\end{array}$} & $2^{\prime}$ & $10^{\prime \prime}$ & $401^{\prime \prime}$ & 2590 & \multirow{4}{*}{$\begin{array}{l}\text { A } 3808^{\circ} \\
\text { B-0 } 813 \\
\text { C-1 } 886\end{array}$} \\
\hline Methitural $c$ & $(50)$ & $58 \%(29)$ & .07 & & $70^{\prime \prime}$ & $1^{\prime \prime}$ & $212^{\prime \prime}$ & 2362 & \\
\hline Methitural s & $(57)$ & $70 \%(40)$ & .06 & & $90^{\prime \prime}$ & $5^{\prime \prime}$ & $24.9^{\prime \prime}$ & 2323 & \\
\hline Methitural (exp) s & (42) & $60 \%(25)$ & .08 & & $6^{\prime}$ & $5^{\prime \prime}$ & $167^{\prime \prime}$ & 2005 & \\
\hline
\end{tabular}

Significant $(P<05)$

${ }^{*}$ Highly significant $(P<01)$

S D. Standard Devation

\section{Relaxants (Table XVI)}

Relaxants, usually small doses of succinylcholne, were given whenever muscular relaxation was inadequate for proper bimanual pelvic examination Whereas they were rarely needed when methitural was being used, and then usually only in those patients who were moving vigorously or were coughing, they had to be used rather frequently in the patients receiving smooth sodium thiopental anaesthesia. The incidence of 34 per cent for sodium thiopental is striking and the difference in comparison $\mathrm{A}^{\prime}$ with sodium methitural was significant. Sodrum methitural, then, had slight relaxant properties This relaxation would not have been adequate for abdominal operations but was enough to allow a thorough and unimpeded pelvic palpation.

TABLE XVI

\begin{tabular}{lcccc}
\hline & & & S D & $t$ \\
\hline Thiopental c & $(50)$ & $34 \%(17)$ & 07 & A $3377^{* *}$ \\
Methitural c & $(50)$ & $8 \%(4)$ & 04 & B 0196 \\
Methitural s & $(57)$ & $7 \%(5)$ & 03 & C 0 417 \\
Methitural (exp) s & $(42)$ & $5 \%(2)$ & 03 & \\
\hline
\end{tabular}

Signi?cant $(P<.05)$

*High y significant $(P<01)$

S.D. Standard Deviation $t$ : Comparzson 
Emergence from Anaesthesia (Table XVII)

Emergence from anaesthesia usually was quite smooth after both thiopental and methitural. However, hiccough was prominent following methitural and coughing was occasionally encountered. Restlessness was relatively more common in the unpremedicated group. Vomiting and retching were seen after both agents, with a somewhat smaller incidence followng methitural with premedicatıon. Most patients were more quickly orientated following methitural than following thiopental.

TABLE XVII

\begin{tabular}{|c|c|c|c|c|c|c|c|c|c|c|}
\hline & & 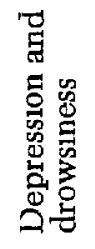 & 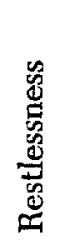 & 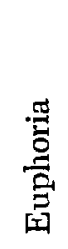 & 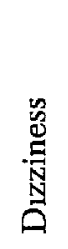 & $\frac{50}{\stackrel{5}{\Xi}}$ & 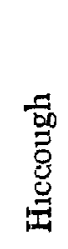 & 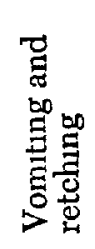 & $\frac{\stackrel{a}{0}}{\stackrel{0}{0}}$ & 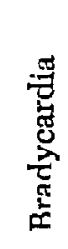 \\
\hline $\begin{array}{l}\text { Thiopental c } \\
\text { Methitural c } \\
\text { Methitural s } \\
\text { Methitural (exp ) s }\end{array}$ & $\left.\begin{array}{r}50 \\
50 \\
57 \\
4.2\end{array}\right)$ & $\frac{1}{1}$ & $\begin{array}{l}-1 \\
1 \\
4 \\
5\end{array}$ & $\overline{\overline{4}}$ & $\frac{1}{-}$ & $\frac{\pi}{2}$ & $\begin{array}{l}-6 \\
4 \\
4\end{array}$ & $\begin{array}{l}5 \\
2 \\
4 \\
6\end{array}$ & $\frac{\bar{Z}}{2}$ & $\frac{-}{1}$ \\
\hline
\end{tabular}

\section{Postoperative Period (Table XVIII)}

There was little difference between thopental and methitural with premedication. There were more undesirable side-effects when methitural was given without prèmedication

TABLE XVIII

\begin{tabular}{|c|c|c|c|c|c|c|c|c|c|}
\hline & & 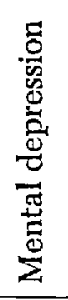 & 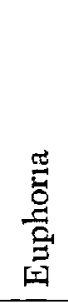 & 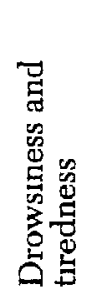 & 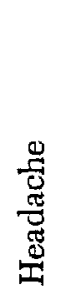 & 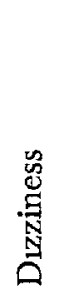 & 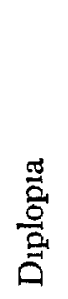 & 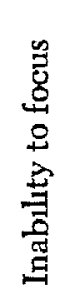 & 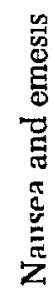 \\
\hline $\begin{array}{l}\text { Thiopental c } \\
\text { Methitural c } \\
\text { Methitural s } \\
\text { Methitural }(\exp ) \mathrm{s}\end{array}$ & $\begin{array}{l}(50) \\
(50) \\
(57) \\
(42)\end{array}$ & $\bar{z}$ & $\frac{-}{1}$ & $\begin{array}{l}1 \\
3 \\
3 \\
-\end{array}$ & $\frac{-}{1}$ & $\begin{array}{l}2 \\
2 \\
7 \\
4\end{array}$ & $\frac{-}{2}$ & $\frac{-}{4}$ & $\begin{array}{l}- \\
5 \\
6\end{array}$ \\
\hline
\end{tabular}

\section{SUMMARY}

The properties of methitural with and without premedication have been compared in a series of patients in physical status I and II and of comparable age, herght and weight, undergoing minor gynaecological procedures.

Sodium thiopental was approximately twice as potent as sodium methitural, and for comparable depth and duration of anaesthesia, the wakıng period after methitural was the same as that following thiopental. 
The incidence of cough and hiccough was greater under methitural anaesthesia. Hiccoughs, when they occurred, tended to persist throughout the procedure and were also seen in the emergence period. Gross movements were seen only with methitural. Patients were more widely awake and less disorientated after methitural anaesthesia, but showed a higher incidence of nausea and vomiting. The apnoea following an induction dose of methitural was on the average of shorter duration than that following sodium thiopental and its incidence was lower. Muscle relaxation for such procedures as bimanual pelvic examination was more often satisfactory with methitural anaesthesia.

Preoperative medication reduced the amount of methitural required to maintain anaesthesia and decreased the incidence of sidé-effects.

\section{ACKNOWLEDGMENTS}

The authors thank the staff of the Department of Obstetrics and Gynaecology for their forbearance with what was on occasion decidedly poor anaesthesia and Dr. E. T. Thomas of the Department of Anaesthesia for his help in preparmg the manuscript. Statistics were done by $\operatorname{Dr} \mathrm{N}$ Shklov, Department of Mathematics, University of Saskatchewan.

\section{RÉSUMÉ}

Nous avons étudié les propriétés du méthitural avec et sans prémédication chez ún certain nombre de malades dont l'état physıque était classifié I ou II, à peu près du même, âge, du même pords et de la même taille, malades qui devalent subir des interventions gynécologiques mineures.

Le thropental sodium était environ deux fors plus puissant que la methitural à profondeur et durée égales d'anesthéste, le révell avec les deux médicaments survenart dans le même délai

La toux et le hoquet survenaient plus fréquemment avec le methitural Quand un malade faisait du hoquet, il avart tendance à en faire durant toute l'opération et même au révell. On a observé des mouvements importants seulement avec le methitural.

Les malades ont semblé plus complètement réveıllés et moins désorientés après l'ànesthésie au méthitural mais les nausées et vomissements ont été plus fréquents.

L'apnée, à la suite de la dose d'inductıon, a duré moins longtemps avec le methitural qu'avec le thiopental et elle est apparue moins souvent. Pour des manœuvres comme un examen bimanuel du bassin, le relâchement musculaire nous a semblé plus satisfaisant avec le mèthitural.

Une prémédication a pour effet de diminuer la quantité de méthitural nécessaire pour maintenir l'anesthésı et diminuer aussi l'appantion des effets indésirables. 


\section{REFERENCES}

1. Schering Corporation Neraval Sodum Promotional booklet 'Bloomfield, New Jersey

2 Blake, M. W., \& Perrlanan, P. L. Metabolism of the Ultra Short-acting Thobarbiturate, Methitural (Neraval®). J. Pharmacol \& Exper Therap 117. 287-297 (1956).

3 Boone, J. D, Munoz, R, \& Dillon, J B Neraval Sodium. A New Ultra Short-actung Thiobarbiturate-Prelımmary Clinical Investigations Anesthesiology 17(2) 284 (1956).

4 Fitzpatrick, L J, Clanie, D’A G, \& Mersch, M A Methitural Sodıum (Neraval(1) Sodrum) A New Ultra Short-acting Intravenous Anesthetic Anesthesiology 17(5). 648-689 (1956).

5 Irwin, S, StagG, R. D, Dunbar, E, \& Govier, W ,M Methitural, A New Intravenous Anaesthetic: Companison' with Thiopental in the Cat, Dog and Monkey J. Pharmacol \& Exper. Therap $116 \quad 317-325$ (1956).

6. O'Herlihy, D B, Nishmura, N, Little, D M, JR, \& Toveli, $R$, M. The Clinical Usage of Neraval Canad Anaesth Soc J 3 326-334 (1956)

7. Flemirng, S. A., \& Robinson, J G Neraval Sodium A Clinical Investigation Canad Anaesth Soc J 4(1) 52-54 (1957)

8. GALE, A,S Recovery from Thiopental and Methitural-Nitrous Oxide Anaesthesia for a Standard Short Procedıre Anesthesiology 18(4) 573 (1957)

9 Houde, J, Hudon, F, \& Jacetes, A Neraval (Methitural Sodium (SCH 3132) Canad Andesth Soc J 4(1) 43-46 (1957)

10 Rosales, J K, Denis, R, \& Gilbert, R G B Development of the Newer ThioBarbiturates Used in Anaestbesia Canad Anaesth Soc J 4(4) 405-413 (1957)

11 Sмrтr, C Methitural Sodiurt for the Induction of Paediatric Anaesthesia Canad Anaesth Soc. J 4(4) 378-383 (1957)

12 Dobkin, A, B, \& Wyant, $G$ M. The Physiological Effects of In ravenous Anaesthesia on Man Canad Anaesth Soc J 4(3) 295-337 (1957)

13. Wy 1 NT, G M, Dobkin, A B, \& AasheIm, G M Comparison of Seven Intravenous Andesthetic Agents in Man Brit J Anaesth 29(5) 194-209 (1957) 